\title{
SCHOOL COUNSELLORS' ROLES IN THE IMPLEMENTATION OF UNIVERSAL BASIC EDUCATION [UBE] SCHEME IN NIGERIA
}

\author{
ARHEDO, Philip Azetta PhD \\ ADOMEH, Ilu O. C. PhD \\ ALUEDE, Oyaziwo PhD \\ Dept of Educational Foundations and Management, \\ Faculty of Education \\ Ambrose Alli University, Ekpoma, Edo State, Nigeria \\ oyaziwoaluede@yahoo.com
}

\begin{abstract}
The Universal Basic Education (UBE) scheme, which came into existence in September 1999, was lauded by the Federal Government of Nigeria as a preferred programme of Nigeria's basic education service. It is expected to provide full and compulsory education from primary one all through to junior secondary school 3 (that is nine years of compulsory schooling). This paper discussed ways in which Universal Basic Education (UBE) could be successfully implemented in order to attain national integration and development. The review of relevant literature shows that lack of resources and political manipulation of programmes are the two critical problems that could hamper a successful implementation of UBE. To get the dividends of Education For All (EFA) by 2015, we need the services of school counsellors in order to be able to implement the UBE programmes successfully. The paper thus recommended that the three-tiers of government local, state, and federal must utilise the services of school counsellors in order to successfully implement the scheme in Nigeria.
\end{abstract}

Key words: Mass literacy, School success, literacy education, compulsory education

\section{Introduction}

Universal Basic Education (UBE) is a reformed programme in Nigeria's basic education delivery (from primary one, all through to junior secondary school class 3 ) and is to reinforce the implementation of the National Policy on Education (NPE) in order to provide greater access and ensure quality throughout the Federation as it is free and compulsory (Adomeh, Arhedo \& Omoike; 2007). Importantly, Nigeria is adopting 
UBE and as a process of fulfilling the aim of Education For All (EFA) as endorsed at the World conference on education held in Jomtien in 1990. According to the world conference on education, basic education is made free and available to all and sundry, thus emphasizing free access, equity, efficiency, literacy, numeracy and life long skills for all.

Therefore, UBE is being implemented in Nigeria as a lasting legacy for the eradication of illiteracy. The Federal Government intervention is quarterly (4 times in a year), and a counterpart fund of equal amount is expected from the states and is expended as follows: Nursery (5\%), Primary (60\%) and Junior Secondary School (35\%), while it is disbursed in each level of education as follows: infrastructure (70\%), manpower development (15\%), and instructional material (15\%) (Ekpunobi, 2006). To achieve this laudable goal, a 9-year continuous free and compulsory education was proposed for immediate implementation.

Following the declaration by the Federal Government of Nigeria for the introduction of 9-year free and compulsory basic education structures, which cover the primary and Junior Secondary School strategies have been put in place by the Nigerian Educational Research and Development Council (NERDC) to re-structured and re-align the school curricula for the 9-year basic education (Obioma, 2006). A total of 19 curricula have been produced to cover the Junior Primary (years 1 - 3) Senior Primary (years 4 - 6) and Junior Secondary School (JSS) (years 7 9). Primary science has been replaced by Basic Science and Technology for Junior and Senior Primary School levels, while Integrated Science has been replaced by Basic Science for JSS level (Nneji, 2006; Obong, 2006). A major gain from this educational system is that the contents of the new curricula reflect both the emerging issues and national values.

It is worthy to mention here that the roles being played by the Notational Commission for Mass Literacy Adult and Non-Formal Education (NMEC) in preparation for the smooth take off UBE. The Commission has the mandate to eradicate illiteracy in Nigeria. In spite of all the reforms in the education sector: a lot of school age children still drop out of school for many socio-cultural and economic reasons. Many adults are also unable to take advantage of existing literacy programmes for many socio- cultural and economic reasons. In an effort to fulfil her mandate and meet the EFA goals of eradicating 50 million illiterate living in Nigeria out of the world 171 million illiterates world-wide, NMEC is partnering with United Nations Educational, Scientific and Cultural Organization (UNESCO) and United Nations Children's Find (UNICEF) in a programme: "Increasing Access to Community Education and Literacy (Adomeh et al, 2007; Nkwoma, 2006) 
No doubt, the understanding of the aims and objectives of Universal Basic Education [UBE] is the first step towards the successful implementation of the programme in Nigeria. Thus, this paper presents a concise definition of Universal Basic Education and the role school counselling can play by partnering with stakeholders [government, school authorities, classroom teachers, parent and pupils] in the successful implementation of universal basic education in Nigeria.

\section{The Meaning, Relevance and Needs of Universal Basic Education}

The Universal Basic Education Act of 2004 states that (without prejudice to the provision of item 30 of part 11 of the second schedule and item (2) of the Fourth schedule of the 1999 constitution dealing with primary school education), the Federal Government's intervention under this Act shall only be an assistance to the States and Local Governments in Nigeria for the purposes of uniform and qualitative basic education throughout Nigeria. Specifically;

i. Every Government in Nigeria shall provide free, compulsory and universal basic education for every child of primary and junior secondary school age.

ii. Every parent shall ensure that his/her child or ward attends and completes his /her primary school education and junior secondary school education by endeavouring to send the child to primary and junior secondary school.

iii. The stakeholders in education in a local government area shall ensure that, every parent or person who has the care and custody of a child performs the duty imposed on him/her under section 2(2) of this Act.

iv A parent who contravenes section 2 (2) of this Act commits an offence and is liable-

(a) On first conviction to be reprimanded;

(b) On Second conviction to a fine of N2,000:00 or imprisonment for a term of one (1) month or both and

(c) On subsequent conviction, to a fine of five thousand Naira $(\mathrm{N} 5,000.00)$ or imprisonment for a term of two (2) months or both.

Obioma (2006) summarised the objectives of UBE as follows: To ensure gender empowerment, value orientation, poverty eradication and create opportunity for all. For a proper take off and possible sustenance of the UBE programme, educational departments such as Universal Basic 
Education Commission (UBEC), and Nigerian Educational Research and Development Council (NERDC) are making bold drives and commitments to human development and materials provision for the successful implementation of UBE in Nigeria. For instance, the UBE programme is expected between 2006 and 2008 to achieve a one hundred percent transition of school age children in admission and promotion from one class to another, at least sixty percent or more instructors trained to meet staffing demand; have fifty percent of school managers computer literate; eliminate gender inequality and ensure a one hundred percent awareness of HIV/ AIDS especially information of the danger.

Like every other enterprise, the success of UBE depends solely on the provision of adequate resources. Adequate resources include proper funding, employing and sustaining enough qualified teachers and good functional infrastructures. UBE Act (2004) stresses that the implementation of the Universal Basic Education shall be financed from (a) Federal Government block grant of not less than $2 \%$ of its consolidated Revenue fund, (b) funds or contributions in form of Federal guaranteed credits and (c) Local and international donor grants

The UBE Act of 2004 also emphasised that for any state to quality for the Federal Government block grant pursuant to sub-section 1(1) of this section, such state shall contribute not less than $50 \%$ of the total cost of projects as its commitment in the execution of the project. The administration and disbursement of funds shall be through the state Universal Basic Education Board (UBE Act, 2004).

Nevertheless, experts argued that the UBE programme may collapse due to inadequate funding, lack of enough qualified teachers and poor infrastructure (Olori, Ibukun, Oyedeji \& Tahir, 2005). Lack of resources could manifest in the following ways: corruption, lack of infrastructure, lack of enough qualified teachers, overcrowded classroom, and increased admission without corresponding increase in manpower and infrastructures needed to manage the programme. Others include, dilapidated structures, unpaid salaries of workers in the education sector, incessant withdrawal of qualified manpower from the education sector, and lack of cooperation among the three - tiers of governments. Also, politicisation of the programme, ethnicisation of the supervisory committee and the current academic qualification discrepancies for the teachers participating in the scheme, may hinder the success of the UBE programme in the Country.

It is good to recall here that Nigeria in the early 1970s, the Federal government introduced the universal primary education (UPE) programme, which made primary education free but not compulsory. 
The programme recorded mass enrolment of pupils, but it became a colossal failure because of corruption, lack of infrastructure and lack of enough qualified teachers. The universal basic education (UBE) programme launched in 1999 to provide compulsory and qualitative education at primary school and junior secondary school levels in Nigeria could become another failure because of funding, lack of infrastructures and employing only few qualified teachers. This type of programme always has increase in enrolment, and without adequate resources being provided to meet the needs and aspirations of the increased enrolment could lead to a collapse.

Olori et al (2005) argued that it is not that government is not giving money but there is a gap. The demand for education is growing higher everyday but the available resources are not keeping pace in terms of the development. In support of this, UNESCO's Education For All (EFA) Global Monitoring Report (2005) provides a detailed analysis of factors influencing the quality of education in several regions of the world, which it says could prevent many countries from achieving Education for All (EFA) goals by 2015. And these include lack of financial and material resources for schools, the number of teachers and their training, the amount of actual learning time, facilities and leadership. To sum up this, Olori et al (2005) stressed that though the UBE programme is good, experiences over the years show that only non - politicisation of the scheme could pave the way for UBE's effective execution.

Lamenting on the state of primary education in October 2006, Sokoto Governor Attahiru Bafarawa on tour of educational institutions in the state declares, "Limited resources have led to inadequate infrastructure and qualified teachers, overcrowded classrooms and dilapidated buildings, forcing pupils especially in rural areas to take their lessons under trees in some cases". He described the situation as a disappointment and a disaster. Thus, if Nigeria is to move rapidly away from the crushing level of illiteracy, a massive injection of uninterrupted funds will have to be ensured (Olori et al, 2005 \& Obong, 2006). Dike (2005) opined that teachers should be properly trained in modern technologies in order to enable them educate students who would be expected to function effectively in their modern work environment and to compete in the global market place.

Roles of school counsellor in the successful implementation of UBE

School counsellors have lots of roles to play towards the successful implementation of UBE as demanded professionally and by partnering with stakeholders in the following perspectives: School counsellors are by 
training and practice strategists in the implementation of education policies. Universal basic education must therefore be implemented with full guidance of the school counsellors. From the point of programme development, to the point of its implementation, the school counsellor's services are indeed worthwhile and indispensable. Thus, school counsellors should help to organise orientation for various categories of new entrants into the various categories of schools, such as Junior Primary, Senior Primary and Junior Secondary Schools, for both staff and pupils. School counsellors must team up with administrative and teaching staff in order to direct adequate and maximum utilisation of school resources by helping individual members of the school community to identify their benefits and personal responsibilities in handling the available resources.

To achieve maximally in this programme, it is expected that the classroom teacher uses good learning materials and improvise where necessary. Special children, with special gifts should be adequately occupied. UBE as a programme has no room for repetition. Since children are promoted yearly en-mass, cumulative records should be kept so that at the end of the compulsory nine (9) years. It is this regard that the counsellors should be able to counsel the child adequately for a proper placement in senior secondary school. In addition, the school counsellors should supervise the submission and documentation of relevant data about the children in their schools, which will be relevant in the long run in the proper placement of the children in the future.

It is the duty of school counsellors to educate the parents of their responsibilities towards their children at school. The roles of the parents here are to complement the government's efforts. For instance, the children at school need uniform good enough for school attendance. Parents are to provide uniform for their children. School counsellors should impress on the parents to live up to their responsibilities by providing their children and wards with the recommended school uniform. School counsellors should let the parents know that they must not force their children into "menial" jobs like truck pushing or sales of sachet water at this age.

School children need the services of school counsellors at school to resolve academic, social, and personal problems. The first week at school, the school counsellors should take these children through orientation, like visiting important places in the school premises. In the process the pupils/students are exposed to the first rules of obedience to bell for assembly, break or closing. They should also be shown places where to urinate, defecate, or where to get water and snacks. In addition, it is the 
duty of school counsellors to imbibe in the children the habit of serious academic work, and use of leisure time for recreation. School counsellors should be able to maintain good rapport with the children. This will enable counsellors to attend to children with social and other personal problems.

Children need people whom they will confidently trust. As confidants, the guidance counsellor should not betray the trust. But when there are incidents of threats to life or spiritual instability, the school counsellors should be able to convince the children why what they want to do must be avoided or be reported to their parents. Parents should also be counselled not to withdraw their children from school for early marriage or undertake forced labour (menial jobs) such as hawking, truck pushing or other forms of human trafficking experiences. Counsellors must remind them of the provisions of the Federal Republic of Nigeria Constitution of 1999 regarding the punishment to be meted on parents/guardians who engage their children/wards in child labour.

\section{Conclusion}

Universal Basic Education (UBE) is a reformed programme of the Federal Government of Nigeria aimed at reinforcing the implementation of the national policy on education. UBE covers both formal and informal education of children 3 - 14 years of age. That is, it covers Pre-school (3 5), Junior Primary $(6-8)$, Senior Primary $(9-11)$ and Junior Secondary $(12-14)$ years of age.

The roles of the school counsellors in the successful implementation of UBE have been emphasized. Therefore, the functionality and eventual successful implementation of the UBE scheme will depend to a large extent on how much the students can avail themselves of the counselling services that may be geared towards the success of the scheme and their eventual future placement opportunities.

\section{References}

Adomeh, I.O.C, Arhedo, A. and Omoike, D. (2007) Contemporary issues in history of education in O.O. Aluede \& D. Omoike (eds.): trends in history of education in Nigeria (pp 221 - 139) Agbor: Krisbec Publications $121-139$.

Dike, V. (2005): Lack of Resources Threaten UBE: News from Africa, Lagos, Nigeria. Retrieved on July 1, 2008 from http:// www.newsfromafrica.org/newsfromafrica/articles/art$\underline{9114 . h t m l}$ 
Ekpunobi, A. N. (2006, August 13-19): Universal basic Education Commission. Paper presented at the 47th Annual Conference of Science Teachers Association of Nigeria held in Calabar.

Federal Republic of Nigeria (1999): Constitution of the Federal Republic of Nigeria, Abuja: Author

Federal Republic of Nigeria (1999): National Policy of Education (Revised). Abuja: Author

Nkwoma, C. A. (2006): Data Analysis for Male / Female Ratio in Science technology and mathematics (STM) Education. STAN: Gender and STM Education series

Nneji, L. (2006, August 13-19): National Officers Reports at the STAN Annual Conference in Calabar; Nigerian Educational Research Development Council: NERDC, Science Teachers Association of Nigeria, 13 - 19 August.

Obioma, G. (2006, August 13-19): The Role of Teachers in the implementation of UBE in Nigeria: Paper presented at the 47th Annual Conference of STAN in Calabar.

Obong I. J. O (2006, August 13-19): The State of Basic Education in Nigeria: Paper presented at the $47^{\text {th }}$ Annual Conference of STAN, in Calabar

Olori, T.; Ibuku, W.; Oyedeji, L. and Tahir, G.. (2005): Lack of Resources Threaten

UBE. http://www.newsfromafrica.org/newsafrica/articles/art9114.html.

The Counselling Association of Nigeria [1991] Roles and functions of school counsellors; Dept of Guidance and Counselling, University of Ibadan, Ibadan, Nigeria

Universal Basic Education (UBE) Act (2004): The compulsory, free, universal Basic Education Act and other relate matters. Abuja: UBE.

UNESCO Global Report (2005): Education for All (EFA) Global Week, Magazine. 